Прегледни чланак

341.231.1:504

doi:10.5937/zrpfns52-17811

Gordana N. Preradović, LL.M., Ph.D. Student

University of Banja Luka

Faculty of Law Banja Luka

preradovic.goga@gmail.com

\title{
THE INTERNATIONAL LEGAL RESPONSIBILITY OF STATES FOR CLIMATE CHANGE
}

\begin{abstract}
Climate change has far-reaching adverse consequences on ecosystems, human lives and health as well as on economic progress, so the question arises whether the state is resposible for climate change and its adverse effects or whether relevant international documents dealing with climate change (UN Framework Convention on Climate Change, Kyoto Protocol and Paris Agreement) should prescribe and define responsibility of a state (or more states) for climate change and its adverse effects which occur due to non-compliance with obligations assumed by the above-mentioned international documents. In the climate change context the primary obligation of the state is to reduce its greenhouse gass emission and thus to protect the atmosphere as the common good of all mankind. Recently increasing attention has been paid to adaptation to the adverse effects of climate change and to obligations of developed countries to assist the least developed countries and developing countries, which are at the same time the most vulnerable to the adverse effects of the climate change, when financing and implementing adaptation measures. The paper also analyzes the grounds and elements of general international liability of states for wrongful acts, as well as international customary rules - no-harm rule and due diligence standard of a country's behavior, as sources of the international resposibility of countries that violate these customary legal rules.
\end{abstract}

Keywords: climate change, international state responsibility, compliance mechanism.

\section{INTRODUCTION}

The report from the Intergovernmental Panel on Climate Change (Intergovernmental Panel on Climate Change, hereinafter referred to as IPCC) ${ }^{1}$ clearly

\footnotetext{
${ }^{1}$ Web page of IPCC: http://www.ipcc.ch/, 15/3/ 2018

${ }^{2}$ Climate Change 2014 - Synthesis Report - Summary for Policymakers, http://www.ipcc. ch/pdf/assessment-report/ar5/syr/AR5_SYR_FINAL_SPM.pdf, 07/ 4/2018 - The warming of the
} 
shows the extent of damages occurring in regions around the world caused by climate change. IPCC has reported that the claims of changes in the climate system are based on the following independent evidence: the atmosphere and oceans have warmed the amount of snow and ice has decreased, the mean global sea level has increased, the concentration of greenhouse gases has risen. The report also warns of continued greenhouse gas emissions that cause further warming and changes in all components of the climate system. Limiting climate change requires a significant and permanent reduction of greenhouse gas emission. ${ }^{2}$

The first part of this article deals with general responsibility of states for violations of international law and about the elements of this responsibility. The second part analyses and explores whether international law has the capacity to deal with complex situations such as the defining international responsibility for climate change and damages caused by climate change, through the analysis of the relevant provisions of the UN Framework Convention on Climate Change. The third part elaborates the mechanism of compliance with the obligations laid down in the Kyoto Protocol which serves as a model of action in matters of state responsibility in the field of climate change. The fourth part gives a chronological overview of the concept of "climate damage" in the negotiations on climate change after the Kyoto Protocol through the documents adopted at the sessions of the Conference of the Parties, including the Paris Agreement. The fifth part analyses international customary law rules that are the basis of states' responsibility for climate change, primarily the no-harm rule and the concept of due diligence. The sixth part states final conclusions reached after conducting analyses.

The possibility of establishing states' responsibility for damages due to climate change in terms of violation of fundamental human rights is an issue that is beyond the scope of this article, but it is very challenging and worth studying since the harmful effects of climate change affect some of the basic human rights of people around the world, especially disadvantaged and vulnerable groups, who

climate system is clear-cut, says the Fifth Assessment Report of the Intergovernmental Panel on Climate Change, while the reconstruction of the Earth's surface temperature over the past 1500 years suggests that the recent warming is unprecedented during this period, which leads to a drastic difference in the rate of change.

${ }^{2}$ The key problem is, precisely, the rate of change that can exceed our ability to adapt. See Christina Voigt, "State responsibility for Climate Change damages", Nordic Journal of International Law, vol. 77, 1-2/2008, 2. - Small island states are particularly vulnerable to the effects of climate change, as rising sea levels and extreme weather events lead to the damage and destruction of vital infrastructure and devices that make life easier for the island's communities. There is a huge number of people on the African continent who are exposed to increased water scarcity due to climate change (780 million people lack access to healthy water sources, and it is estimated that one third of the world's population lacks adequate sanitation). According to the World Health Organisation, every day around 3,900 children die due to the use of dirty water and poor hygiene. Every year 3,41 million people die from lack of water, sanitation and poor hygiene. Sources: http://blueplanetnetwork.org/water/ and http://www.un.org/waterforlifedecade/background.shtml, 22/ 5/ 2018 
have not contributed to these changes and have the least capacity to adapt. In this context, the concern for protecting the basic human rights is also the fight against climate change and its adverse consequences. ${ }^{3}$

\section{RESPONSIBILITIES OF STATES FOR INTERNATIONALLY WRONGFUL ACTS}

The International Law Commission codified the general rules of international responsibilities of states in the Draft Articles on Responsibility of States for Internationally Wrongful Acts (hereinafter referred to as the Draft). ${ }^{4}$ In order to determine the responsibility of a State, it must be confirmed that the State has committed a wrongful act. The secondary rules of a State's responsibility are applicable only if the conduct of a State constitutes a breach of primary international obligations. ${ }^{5}$ International Court of Justice has applied the principle under Article 1 of the Draft in numerous cases, advisory opinions on reparation for damage as well as in the interpretation of treaties. ${ }^{6}$ Arbitral tribunals have also confirmed this principle on several occasions. ${ }^{7}$ It is obvious that, much earlier before or after the International Law Commission has formulated Article 1 of the Draft, there has always been a widely recognised principle that every wrongful act of a State entails international responsibility. ${ }^{8}$ There are different opinions on the issue of

\footnotetext{
${ }^{3}$ Rodoljub Etinski, "Climate change and changes in the international order," Climate change - Legal and Economic Challenges, Yearbook, editor Stevan Lilić, Faculty of Law of the University in Belgrade Centre for Publishing and Informing, 2011, 78 - 81. See Bojan Tubić, "Access to the 'international justice' (Jurisdiction of international courts) in the field of environmental protection", Yearbook of the Law Faculty in Novi Sad, 3/2014, 321-335. See Svitlana Kravchenko, "Procedural Rights as a Crucial Tool to Combat Climate Change", Georgia Journal of International and Comparative Law, School of Law, University of Georgia, vol. 38, 3/2010.

${ }^{4}$ Draft Articles on State Responsibility for Internationally Wrongful Acts, with commentaries (2001), Yearbook of the International Commission, vol. II, Part Two, 2001.

${ }^{5}$ Articles 1-3 and 12-5 of the Draft

${ }^{6}$ Corfu Channel case in the Military and Paramilitary Activities in and against Nicaragua case (Nicaragua $v$. USA), Merits, Judgment, I.C.J. Reports, 1986; Reparation on Injuries Suffered in the Service of the United Nations, Advisory Opinion, I.C.J. Reports, 1949; Interpretation of Peace Treaties with Bulgaria, Hungary and Romania, Second Phase, Advisory Opinion, I.C.J. Reports, 1950.

${ }^{7}$ International Fisheries Company (USA) v. United Mexican States, Report of International Arbitral Awards, vol. IV, 1931, 691-746; Armstrong Cork Company Case - Decision No. 18, vol. XIV, 1953, 159-173; Rainbow Warrior Case (New Zealand v. France), Report of International Arbitral Awards, vol. XX, 1990, 215-284.

8 On earlier different approaches to defining the legal relations arising from the international unlawful act, see Dionisio Anzilotti, "Corso di diritto Internazionale", 4th ed., CEDAM, Padua, 1955, 385 and Ian Browlie, "Principles of Public International Law", 5th ed. Oxford University Press, 1998, 435, according to ILC Yearbook of the International Commission, vol. II, Part Two, 2001, 33 .
} 
whether the legal relations arising from the international unlawful act are bilateral, so that they only concern the responsible State and the affected State. However, it is increasingly being recognised that certain wrongful acts involve the responsibility of a State towards several or more countries, or even to the international community as a whole. ${ }^{9}$ Article 2 of the Draft stipulates that there is internationally wrongful act of a State when the conduct consisting of an action or omission: (a) can be attributed to the State under international law and (b) constitutes a breach of an international obligation of the State. ${ }^{10}$ The Commission in its Comments confirmed that there are no exceptions to the principle confirmed in Article 2 of the Draft, where two necessary conditions for the existence of an international wrongful act have been prescribed. Furthermore, a question has been posed: whether these two conditions are sufficient, because sometimes the international responsibility cannot be determined by a mere fact that a certain State does not comply with its obligations, as long as there are no certain elements, particularly a damage to another State. Requirement of additional elements depends on the content and interpretation of the primary obligation, and there is no a general ru-

${ }^{9}$ A significant step in this direction has been taken by verdict of the International Court of Justice in Barcelona Traction case of 1964, in which the Court stated that the essential distinction should be drawn between the obligations of a State towards the international community as a whole, and those arising vis-à-vis other countries in the field of diplomatic protection. In the first situation it comes to protecting rights, which is the interest of all countries, and therefore it is about the obligations that operate erga omnes. With regard to the comments that the Commission has made on this issue, one may wonder whether the attitude of the Commission on the responsibility of one or more states towards a number of other states or the entire international community can be applied when it comes to responsibility and damages caused by climate change? For example, the application of countermeasures that are available to the injured State, in addition to the possibility of seeking compensation for damage, is not appropriate when it comes to the environment, since it is obvious that undertaking countermeasures in terms of e.g. an increase in greenhouse gas emissions of affected countries would have bad consequences for the general status of emissions and harmful consequences of the increase. On application and limitations to the application of countermeasures as a right of injured State to suspend the performance of its other obligations towards the State which has committed international unlawful act, see Rodoljub Etinski, Sanja Đajić, Public International Law, Faculty of Law in Novi Sad, 2012, 270 and 271. See Articles 49-53 of the Draft.

${ }^{10}$ ILC Yearbook, vol. II, Part Two, 2001 34. International Court of Justice named these two elements in Phosphates in Morocco Case (Permanent Court of International Justice, Judgement No. 28,1938 ). The Court explicitly linked the creation of international responsibility with the existence of act that can be attributed to the State and which is contrary to the contract law of another State. Thereby, the Commission in its comments relies on the attitude of the International Court of Justice in the case of United States Diplomatic and Consular Staff in Tehran Case (International Court of Justice, No. 64, 1980) where the Court, in order to determine the responsibility of the Islamic Republic of Iran, said that first of all it should be determined to what extent the particular conduct may legally be attributed to Iran, and secondly, to consider compatibility or incompatibility of such conduct with the obligations of Iran from the agreements that are in force or in accordance with other applicable rules of the international law. 
le in this regard. ${ }^{11}$ Etinski and Djajic state that what is important for determining whether the state has violated the obligation is correct interpretation of obligations, that is, a clear and precise definition of what the state is obliged to do. ${ }^{12}$ The second part of the Draft, which includes the content of the international responsibility of States, stipulates that the State which is responsible for international wrongful act is obliged to: (a) stop the activity, if it continues do so, and (b) if the circumstances require it, to offer appropriate insurance and guarantee that they will not repeat that kind of illegal activity. ${ }^{13}$ A responsible State is obliged to make full reparation for the injury that has been caused by international wrongful act. The injury includes any damage, whether material or moral. ${ }^{14}$ Article 33 of the Draft stipulates that the obligations set out in that part may relate to another State, to several States or to the international community as a whole, depending on the nature and content of the international obligation and on the circumstances of the breach. Full reparation for the injury caused by internationally wrongful act may take the form of restitution, compensation and satisfaction, either in one of these shapes or in combination. ${ }^{15}$ Restitution includes the obligation of the State which has made internationally wrongful act to restore the situation that existed before the act was committed (restitutio in integrum) to the extent which is not materially impossible, and as for the rest part, to make the compensation by covering any financially assessable damage including the loss of profits to the extent as established. ${ }^{16} \mathrm{~A}$ State which has committed wrongful act is obliged to offer satisfaction for the injury caused by the act, if it cannot be made by restitution or compensation. ${ }^{17}$ Articles 40 and 41 of the Draft stipulate rules which determine the legal consequences of a serious breach of the obligations under peremptory norm of international law (ius cogens). Serious breach involves a big and systematic failure of the responsible State to fulfill its obligation under peremptory norm. ${ }^{18}$

An injured State can seek its rights from the relationship of responsibility by the request in which it specifies the conduct that the responsible State should take

${ }^{11}$ ILC Yearbook, vol. II, Part Two, 2001, 36. For example, contractual obligation, that a single law should be passed, has been breached by non-issuance of the law, so it is not necessary that the other Parties indicates any specific damage it suffered because of that failure.

12 R. Etinski, S. Đajić, 253.

${ }^{13}$ Article 30 of the Draft

${ }^{14}$ Responsible States cannot rely on the provisions of its internal law as justification for not meeting their obligations (Article 31 of the Draft).

${ }^{15}$ Article 34 of the Draft. See R. Etinski, S. Đajić, 262-265.

${ }^{16}$ Articles 35 and 36 of the Draft

${ }^{17}$ Article 37 of the Draft. Satisfaction may include recognition of the breach, the expression of regret, a formal apology or another appropriate form, in a way that satisfaction must not be disproportionate to the injury or humiliating to the responsible State.

${ }^{18}$ Articles 40 and 41 of the Draft. States shall cooperate in legal means to bring an end to a serious breach of said obligation, and no country will recognise as legal the situation that is a result of a serious breach of this obligation, nor will it help in maintaining such situation. 
in order to stop breaching the obligation, a form of reparation and measures that the responsible State should take in order to prevent the repetition of breach of obligations in the future. If there are several injured States, each of them can submit their requests individually, and if there are several responsible States, an injured State can apply to each of them, so that the received financial compensation covers the damage. Another State, to which the obligation is owed, and the obligation serves to protect the collective interest of the group, may seek from the responsible State to cease to commit a wrongful act and offer them guarantee that it will not happen again as well as reparations to the injured State. ${ }^{19}$ An injured State is one to which the obligation that has been breached is owed individually, and apart from the injured State, the Commission determines the group of States which, although not injured in the narrow sense, also have the right to hold the responsible State accountable. If the determined obligation is owed to the group of States or the international community as a whole, an injured State is one that is particularly affected by the wrongful act, or any other State if the breach of said obligation radically changes the position of these States in terms of further exercise of their rights and obligations. ${ }^{20}$ In Article 55 of the Draft, the application of the legal principle of "lex specialis derogat legi generali" has been confirmed when it was stated that the articles of the Draft shall not apply where the conditions for the existence of an internationally wrongful act or the content or implementation of the international responsibility of the State are governed by special rules of international law. ${ }^{21}$

\section{STATE RESPONSIBILITY UNDER THE UNITED NATIONS FRAMEWORK CONVENTION ON CLIMATE CHANGE}

In the context of environmental degradation and the occurrence of transboundary damages, the law on States' responsibility has two functions: the first is to support the basic rules established by contract or customary law, whose aim is

${ }^{19}$ R. Etinski, S. Đajić, 269 and 270. In the literature we find the division of subjects of international responsibility on the active and passive. In the Draft, International Law Commission uses more adequate term "injured State" instead of the term "passive subject".

${ }^{20}$ Articles $46-48$ of the Draft

${ }^{21}$ See Richard S. J. Tol, Roda Verheyen, "State responsibility and compensation for climate change damages - a legal and economic assessment", Energy Police 32, 2004, 1116. - United Nation Convention on the Law of the Sea regulates the rights and obligations of States with regard to the specific legal regime of maritime zones and the protection of the marine environment. Article 194.2 of the Convention implicitly prohibits unrestricted greenhouse gas emissions, by committing States to ensure that activities within their jurisdiction and control are conducted so as not to cause damage by pollution to other States and their environment. Article 235 stipulates that States are responsible for the fulfillment of their international obligations regarding the protection and preservation of the marine environment, and that they are responsible in accordance with international law. 
to prevent the occurrence of damage to the environment, while the second is to ensure the injured states the right to restitution and compensation..$^{22}$

Contract law is the main source of obligations in international law of the environment which contains much more defined rules and different obligations than the common law in this field. The existence of contract excludes the application of the general common law between the Parties. ${ }^{23}$ In the international law, this phenomenon is called "self-contained regimes". 24 "In the internal legal systems," says Bodansky "elements of the legal form, the court requirements and enforcement go hand in hand, and this is considerably less common at the international level, because many international agreements, if not most of them, do not contain or provide mechanisms for judicial protection and enforcement." ${ }^{25}$ The central question is whether these contracts contain an obligation on the conduct of States whose breach constitutes the basis of international responsibility (e.g. the obligation of States to take all available measures to avoid damage). The starting point for this analysis is the relationship between the legal framework set in the United Nations Framework Convention on Climate Change (hereinafter referred to as the Convention or UNFCCC $)^{26}$, by Kyoto Protocol ${ }^{27}$ and the Paris Agreement ${ }^{28}$, on the one side, and the general international law, on the other side. Most of these

${ }^{22}$ Christina Voigt, 3, according to Orego Vicuna, "Institut de Droit International - Resolution on Responsibility and Liability: Responsibility and Liability for Environmental Damage under International Law: Issues and Trands" Georgtown Environmental Law Review, 10, 1998, 279. However, there is little concrete evidence that the States recognise their responsibility for environmental damage as a positive incentive to take preventive measures in order to prevent damage, or as means of restitution or compensation. One of the examples is the nuclear accident in Chernobyl, which caused significant damage to many countries of Northern Europe, none of which had tried to apply for compensation from the Soviet Union. The reason for this is partly based on political constraints, but also on the legal uncertainty.

${ }^{23}$ See Matthew Happold, "The relationship between United Framework Convention on Climate Change and other rules of public international law, in particular on States' responsibility for adverse impacts of climate change", 2, available at: http://legalresponseinitiative.org/wp-content/uploads/2013/07/BP43E-Briefing-paper-UNFCCC-and-Lex-specialis-31-January-2013.pdf, $09 / 3 / 2018$

${ }^{24}$ C. Voigt, 3, according to Bruno Simma, "Self-Contained Regimes", Netherlands Yearbook of International Law 16/1985, 115. See ILC Report "Fragmentation of International Law: Difficulties Arising from the Diversification and Expansion of International Law", written by Martti Koskenniemi, A/CN.4/L. 682, 2006, 65 -99. See: Bruno Simma, Dirk Pulkowski, "Of Planets and the Universe: Self-contained Regimes in International Law", The European Journal of International Law,Vol. 17, 3/2006, available at: $h t t p: / / w w w . e j i l . o r g / p d f s / 17 / 3 / 202 . p d f, 11 / 02 / 2018$

${ }^{25}$ Daniel Bodansky, "The Legal Character of the Paris Agreement", Review of European, Comparative and International Environmental Law, 25, 2, 2016, 146

${ }^{26}$ United Nations Framework Convention on Climate Change - UNFCCC. Content of the Convention is available at: https://unfccc.int/resource/docs/convkp/conveng.pdf, 14/2/2018

${ }^{27}$ Kyoto Protocol, available at: https://unfccc.int/resource/docs/convkp/kpeng.pdf, 14/ 3/ 2018

${ }^{28}$ Paris Agreement, available at: https://unfccc.int/resource/docs/2015/cop21/eng/l09r01. $p d f, 05 / 3 / 2018$ 
contracts, says Voigt, do not contain clear basic obligations or secondary rules dealing with the legal consequences of the breach of obligation. ${ }^{29} \mathrm{UN}$ Convention on Climate Change is a framework agreement which left a significant degree of discretion to the Parties to define rights and obligations on their own, from which arises the difficulty to identify the specific obligations of States on the basis of basic obligations contained in this Convention. ${ }^{30}$ The Convention does not contain provisions that define the responsibility of States for non-compliance with obligations which leads to adverse consequences of climate change, but instead it is focused on mitigation measures. ${ }^{31}$ Also, the Convention does not deal with damages due to climate change, nor does it contain provisions dealing with compensation for the damage. ${ }^{32}$ History of negotiation shows that Parties have decided to focus on the provisions on mitigation, rather than to fight against the possible damages that affect people, economies and ecosystems. Yet the Parties are aware of the problem of damage, as reflected in the preamble to the Convention, where it is repeated that the States "have a responsibility to ensure that activities within their jurisdiction or control do not cause damage to the environment of other States or areas beyond the limits of their jurisdiction." ${ }^{33}$

Although Article 2 of the UNFCCC is often interpreted as a non-legally binding text used to set political goals, in legal terms it can be regarded as important because it constitutes the aim and purpose of the Convention in terms of the customary law of contracts. ${ }^{34}$ Therefore, this article can be used as an aid in the interpretation of other provisions of the Convention. Pursuant to Article 18 of the Vienna Convention on the Law of Treaties ${ }^{35}$, which has largely codified customary

${ }^{29}$ C. Voigt, 3, according to M. A. Fitzmaurice and C. Redgwell, "Environmental Non-Compliance Procedures and International Law", Netherlands Yearbook of International Law, 2000, 35-65

${ }^{30} \mathrm{C}$. Voigt, according to Akiko Okamatsu, "Problems and Prospects of International Legal Disputes on Climate Change", available at: http://userpage.fu-berlin.de/ffu/akumwelt/bc2005/papers/okamatsu_bc2005.pdf, 14/11/2017

${ }^{31} \mathrm{M}$. Happold, 2 and 3.

${ }^{32}$ See more on this: R. Tol, R. Verheyen, 1114

${ }^{33}$ See Paragraph 8 of the preamble of UNFCCC. After the ratification of the UNFCCC some Parties have made explicit reserve ensuring that the Convention does not preclude the application of international law on States' responsibility. Declarations that have been drawn up by the Government of Nauru, Tuvalu, Fiji and Papua New Guinea confirm that the provisions of the UNFCCC in any way will not be able to constitute a waiver of any right under international regulations regarding the responsibilities of States for the harmful effects of climate change. Op. cit. C. Voigt; 4

${ }^{34}$ Timo Koivurova, "International Legal Avenues to Address the Plight of Victims of Climate Change: Problems and Prospects", Journal of Environmental Law and Litigation, University of Oregon, 12/2007, 275, according to Roda,Verheyen, "Climate Change Damage and International Law: Prevention Duties and State Responsibility", Yearbook of International Environmental Law, vol. 16, 1/2005, 865-868. See M. Happold, 3.

${ }^{35}$ Vienna Convention on the Law of Treaties (1969) came into effect in 1980 Content is available at: http://untretay.un.org/ilc/texts/instruments/english/conventions/1_1_1969.pdf. 
international law of treaties, a country that signs the Convention should refrain from measures which are contrary to the aim and purpose of the Convention. ${ }^{36}$ Article 4, paragraph 2 of the UNFCCC stipulates that industrialized countries commit to reduce their greenhouse gas emissions by 2000 to the level dating back to 1990, which shows that it does not set specific and concrete goals of reduction of greenhouse gas, therefore some authors and commentators say that the legal status of these provisions is questionable. ${ }^{37}$ One of measurable obligations under the Convention is a procedural obligation of developed countries to report on policies and measures they have taken to reduce their emissions. ${ }^{38}$ And all countries are obliged to report their inventories of greenhouse gases annually. ${ }^{39}$ Because of these shortcomings in terms of clarity and precision of the obligations prescribed in the Convention, the Parties have not reached a high level of compliance with the obligations ${ }^{40}$. The concept is neither mentioned in the Convention nor in the decisions of the Conference of the Parties, but it is more correct to refer to the obligations prescribed by the Convention as the implementation process relating to the measures taken by States in order to put an international agreement in force under domestic law. ${ }^{41}$

Article 13 of the Convention provides that the Conference of the Parties of the Convention shall work on the establishment of a multilateral consultative process, which will be available to the Parties at their request, to address issues related

${ }^{36}$ See D. Bodansky (2016) - Although the UNFCCC, in accordance with the Vienna Convention on the Law of Treaties, is considered a legally binding contract, Article 4.2 of the Convention has been formulated more as a legally non-binding, rather than a legally binding norm.

${ }^{37}$ T. Koivurova, 276. According to Daniel Bodansky, "The United Nations Framework Convention on Climate Change: A Commentary", Yale Journal of International Law, vol. 18, 1/1993, 281-295. See M. Happold, 4. See Xueman Wang, Glenn Wiser, "The Implementation and Compliance Regimes under the Climate Change Convention and its Kyoto Protocol", Review of European, Comparative \& International Environmental Law,

(C) Blackwell Publishers Ltd, 11, 2/2002, 184 - UNFCCC is the first concrete international effort to combat climate change, and because of uncertainties in the science of climate and the situation in the economies of the countries at the time of its adoption, the Convention contains "soft" obligations of the Parties to undertake a general obligation of mitigation and adaptation to climate change.

${ }^{38}$ Article 4, paragraph 2 (b) of the Convention.

${ }^{39}$ Article 4, paragraph (a) of the Convention.

${ }^{40}$ In English, this term denotes the "compliance", which means "agreement", "approval", "submission".

${ }^{41}$ Thus, Article 4.2 of the UNFCCC in conjunction with Article 2 obliges the Parties to take action to adopt policies and measures to stabilize the concentration of greenhouse gases in the atmosphere. Therefore, these two articles together can be understood as a primary rule whose breach is an illegal act. A State commit such an act if it does not take at all or if it takes insufficient measures to modify the growing trend of greenhouse gas emissions. This argument can be supported with reference to the above Article 18 of the Vienna Convention on the Law of Treaties and the principle of good faith. 
to the interpretation and application of the Convention. In the Article 14 it is stated that the settlement of disputes is related to the interpretation or the application of the Convention, thereby the Convention does not contain any provisions related to responsibilities of the States for the adverse effects of climatic changes, which implies that disputes regarding the States' responsibilities are not covered by the provisions of Article 14. Therefore the said article cannot be regarded as establishing lex specialis system in matters of States' responsibility for the breach of provisions of the Convention. ${ }^{42}$ If the Parties want to submit the dispute to the judicial settlement, they must make a written declaration. ${ }^{43}$ Article 14, paragraph 5 of the Convention prescribes the rules for the procedure of conciliation. Starting disputes concerning global warming before the International Court of Justice, says Strauss, would bring significant benefits, but the barriers to their initiation are evident. Only States may file claims against other States before the International Court of Justice. ${ }^{44}$ Conversely, there is a noticeable increase in lawsuits regarding determination of responsibility for contributing to climate change at the national level. ${ }^{45}$ Determining which State or States would most effectively be able to file a suit is not simple, because almost all of us participate in carbon-eco-

${ }^{42}$ M. Happold, 5 - Upon signing the UNFCCC, Fiji stated that by signing the Convention they shall not in any way waive any rights under international law concerning the liability of the State for the harmful effects of climate change, and that no provision of the Convention can be interpreted as to deviate from the principles of general international law. A similar statement during the signing or ratification of the Convention gave Kiribati, Nauru and Papua New Guinea. However, the interpretative declaration is not binding, it serves to those who are making the statement to give their opinion on the meaning and interpretation of the contract or its specific provisions, but this opinion does not bind the other Parties to explicitly deny them. See T. Koivurova 277 according to R. Verheyen, 117.

${ }^{43}$ Only the Solomon Islands and the Netherlands accepted the arbitration as a means of settling disputes concerning the interpretation and application of the Convention with counterparty that also states the same. Apart from arbitration, The Netherlands accepted the jurisdiction of the International Court of Justice, and Cuba did the same. See "International Climate Change" - Six Pump Court, London - presentation by prof. Sands Philippe at Symposium organised by the King's College London, 2015, https:/www.kcl.ac.uk/law/newsevents/eventrecords/ClimateChangeandtheRuleofLawAdjudicatingtheFutureofInternationalLaw.aspx, 20/ 3/2018. See Andrew L. Strauss, "Climate Change Litigation: Opening the Door to the International Court of Justice", School of Law University of Dayton, 3/2009, 341 and 345. In response to the Court's determination to assert its authority in the case of Nicaragua against the United States in 1986, the US withdrew its acceptance of the compulsory jurisdiction of the Court.

${ }^{44}$ Article 34, paragraph 1 of the Statute of the International Court of Justice

${ }^{45}$ See "The Status of Climate Change Litigation - A Global Review", UNEP and Sabin Center for Climate Change Law at Columbia Law School-New York, op. cit. Sabin Center-Arnold \& Porter Kaye Scholer Climate Change Litigation Databases, available at: http://wordpress2.ei.columbia.edu/climate-change-litigation/Since March 2017, in Europe, 24 claims have been filed regarding climate change, while in USA there were 654 such cases and more than 230 in other countries, https://wedocs.unep.org/bitstream/handle/20500.11822/20767climate-change-litigation. $p d f$ ? sequence $=1 \&$ is Allowed $=y, 05 / 02 / 2018$. See Rodoljub Etinski, "National judicial control of 
nomy, and suffer adverse consequences of such action at the same time. It is evident that some States contribute far more to deterioration since they are major emitters of greenhouse gases. ${ }^{46}$ Therefore, the most apparent claimants could be States that contribute least to the problem, which are also most affected, and these are small island states and coastal lowland zones. ${ }^{47}$ The second category of claimants may be the developed countries which carry the greatest burden of fighting climate change, and their complaints would be filed against other developed countries that do not comply with their obligations to share the burden. However, regardless of who would be the complainant to the Court, it is questionable whether the International Court of Justice is competent to adjudicate in these disputes, since its competence is exclusively based on the consent of a State. ${ }^{48}$

\section{THE CASUAL LINK BETWEEN ACTIVITIES AND DAMAGES AND LEGAL CONSEQUENCES OF CLIMATE CHANGE}

Existence of responsibility of the State requires establishing a causal link between activities and the damage. ${ }^{49}$ In the context of climate change, there are

the performance of some obligations accepted from the UN Framework Convention on Climate Change", Facta universitatis, Series: Law and Politics, vol. 9, 1/2011, 19-33.

${ }^{46}$ A. L. Strauss, 338, according to "World Resources Institute Chart of Total Greenhouse Gas Emissions in 2000“, http://cait.wri.org/cait.php?page=yearly, 04/ 4/ 2018. For example, average citizen of USA is responsible for over forty times bigger amount of greenhouse gas compared to the average citizen of Kiribati.

${ }^{47}$ A small Pacific island Tuvalu intended to file a claim against USA to the International Court. See A. L. Strauss, 339, according to Allen Leslie, "Will Tuvalu Dissapear Beneath the Sea? Global warming Threatens to Swamp a Small Island Nations", Smithsonian, 2004, https://www. smithsonianmag.com/science-nature/will-tuvalu-disappear-beneath-the-sea-180940704/, 15/3/ 2018

${ }^{48}$ Consent may be manifested in three ways: the first is that the Parties to the dispute agree to submit the case to the Court pursuant to Article 36, paragraph 1, of the Statute of the Court; Second, if, in accordance with the so-called optional clause in Article 36, paragraph 2, of the Statute, the defendant State brought a prospective statement on acceptance of the compulsory jurisdiction of the Court over the dispute being adjudicated, and if, in accordance with the rules of reciprocity, the State that prosecutes gave permission in its statement; the third way in which the Court's jurisdiction can be obtained, also in accordance with Article 36, paragraph 1 of the Statute, is when the Parties expressly impose that the dispute is to be adjudicated in the Court in the relevant contract in force. See more: Rodoljub Etinski, et al., “Савремени трендови међународноправне заштите животне средине", Yearbook of the Faculty of Law in Novi Sad, vol. 51, 2/2017, 280.

${ }^{49}$ Climate Change 2014 - Synthesis Report - Summary for Policymakers, http://www.ipcc. ch/pdf/assessment-report/ar5/syr/AR5_SYR_FINAL_SPM.pdf, 07/ 4/ 2018. It is useful to distinguish between general and specific causation. The first concerns the general relationship between the increase in anthropogenic greenhouse gas emissions and damage due to climate change. We are not discussing the chain of causation because there is almost universal international scientific consensus on this issue, as evidenced by the reports of the IPCC. Specific causation requires proof that the particular activity causes a particular type of damage. 
evident difficulties to determine if the International Court would accept certain evidence as sufficient and necessary standard of proof for establishing the causal link, precisely because of nonlinearity of the climate system, which in itself involves uncertainty. ${ }^{50}$ The next challenge for determining the causal link is the lack of immediacy between the breach and the damage. ${ }^{51}$ The reason for this is the interweaving of all kinds of physical and chemical processes in the atmosphere, because the increase in greenhouse gas concentration initially starts and causes other natural processes that then lead to injury and damage. For example, the rise in ocean temperatures interferes with the air currents and leads to stronger and more frequent storms. International jurisprudence has accepted the attitude that it does not matter how many links there are in the chain of causation linking harmful effects, but what is important is that the chain is not interrupted. International tribunals believe that governments are only responsible for direct and foreseeable causes of their actions, and they refused requests for compensation for the far-reaching consequences. ${ }^{52}$ When it comes to cases involving damage due to climate change, it is physically impossible to restore the earlier state, therefore the victim country can seek financial compensation to cover the costs associated with material damage to environmental resources (pure environmental damage) and consequential damages suffered by people and property (consequent environmental damage). Voigt says that three separate challenges arise from the given context: (a) evaluation of environmental damage, (b) contribution to incurred damages, and (c) the distribution of damages ${ }^{53}$ Article 31 of the Draft defines the breach as any damage, whether material or moral, caused by the internationally wrongful

${ }^{50}$ The new tendency of establishing the standard of proof has been introduced through the application of the precautionary principle in the case of Southern Bluefin Tuna in which the International Tribunal for the Law of the Sea acted. In this case, this principle has been used as a lower standard of proof in situations where the complexity of the factual situation leads to a greater degree of uncertainty. Southern Bluefin Tuna Case (New Zealand v. Japan, Australia v. Japan), Reports of International Arbitral Awards, 2000, vol. XXIII, 1-57.

${ }^{51}$ However, in the case of Trail Smelter, existence of multiple causes did not deterred tribunal from awarding damages. It seems that the fact that the damage was partly caused by pollution of smelter in Trail in Canada was sufficient. However, the question remains whether the legal theory can develop new theories that might engage in this kind of challenge or legal analysis necessarily end here, says Voigt. See more on this: C. Voigt, 16.

${ }^{52} \mathrm{C}$. Voigt, 17. Yet, it is unlikely that a particular hurricane can be attributed to greenhouse gas emissions of a certain country, despite its devastating consequences. It is somewhat easier to establish a chain of causality between greenhouse gas emissions and other effects of climate change such as flooding due to rising sea levels and loss of frozen land and sea ice. Although there may be many links between gas emissions and the resulting consequences, there is still no interruption of the chain of causation, because all the greenhouse gases that lead to climate change are equally direct in the chain of causality.

${ }^{53} \mathrm{Ibid}$. 18. About key elements that should be handled by regimes on responsibility and compensation for damage caused by climate change and the key principles for choosing between different options for installing regimes, see Roda Verheyen, Peter Roderick, WWF-UK - Climate 
act. Material damage includes all possible losses in infrastructure, property, and the like, including the costs incurred in response to the damage, which, if understood literally, includes adjustment measures. In the context of climate change, material damage is easier to define and evaluate in financial terms than in pure ecological damage.

Adjusting can be legally defined as protection from direct damage, because it may reduce the remaining (residual) damage and thereby reduce the risk of such damage. Residual damage happens when adaptation measures are not possible, or when they are not implemented due to economic or technical limitations. For legal purposes, the obligation to prevent direct damage, which means that adaptation measures are applied, corresponds to the obligation to compensate for any incurred damage. Alleviation is prevention of anthropological climate change at the source by reducing greenhouse gas emissions, or increasing the capacity of the container (storage) of carbon dioxide. Within the legal analysis on responsibility of States for damage from climate change, mitigation can be seen as prevention of "indirect" damage which deals with preventing the actual risk of damage from climate change caused by human activities. Obligation to implement mitigation measures, as such, can be the basis for submitting the application concerning the States' responsibility. ${ }^{54}$

\section{COMPLIANCE MECHANISM PRESCRIBED BY KYOTO PROTOCOL}

Given the large number of international multilateral agreements in the field of the environment, before the governments of the Parties to those agreements and before the International Community, the question of how to make the best implements of the agreements and to comply with the obligations laid down in those agreements has been posed, as well as the question of how to deal with those countries that fail to fulfill their contractual obligations. The traditional adversarial approach to resolving non-fulfillment of contractual obligations, in which countries seek compensation for damage suffered as a result of harmful behaviour, or in which they suspend their execution of the contract in response to a failure of other Parties to fulfill their obligations, has the inherent shortcomings in the international agreements on the environment and protection of common goods, in a way that non-compliance with the obligations by a particular State is harmful for everyone, and undertaking reciprocal measures against that State would only make the situation in the environment worse. Therefore, it is difficult to establish

Change Programme - discussion paper, 2008, 29, available at: http://assets.wwf.org.uk/downloads/ beyond_adaptation_lowres.pdf

${ }^{54}$ Tol, R. Verheyen 1113-1114. 
an efficient mechanism for regulation and control of compliance and enforcement of international multilateral agreements in the field of the environment..$^{55}$

The Kyoto Protocol establishes mechanisms for acting upon undertaking obligations (compliance mechanism). ${ }^{56}$ Unlike the UNFCCC, the Kyoto Protocol establishes legally binding targets of reduction of greenhouse gas emissions for developed countries - countries of Annex I of the obligation period 2008 - 2012. ${ }^{57}$ Furthermore, in contrast to the UNFCCC, as well as most other international multilateral agreements, Kyoto protocol establishes a comprehensive system of compliance mechanism by using the following three phases: (1) reporting, (2) checking and evaluating the compliance mechanism and (3) responding to noncompliance ${ }^{58}$ Committee to monitor the implementation of obligations (Compliance Committee) was established in Marrakesh Accord in 200159, whose jurisdiction is to promote the implementation of obligations by providing advice and assistance to the Parties to the Kyoto Protocol, and to identify cases of non-compliance and to apply appropriate consequences provided for that. It consists of two branches: a branch to make it easier for the Parties to apply the Kyoto Protocol (facilitative branch) and executive branch (enforcement branch). The process of monitoring the implementation of the obligations may be initiated by a question that is: (a) posed in the reports of the expert teams for examinations under Article 8 of the Kyoto Protocol and submitted to the Committee through the Secretariat, (b) filed by any Party regarding itself, or (c) filed by any Party in relation to the other Party. As for the posed question, the Bureau of the Committee for monitoring the implementation determines the jurisdiction of one of the two branches of the Committee, after which the relevant branch carries out a preliminary examination of implementation and decides whether to proceed. ${ }^{60}$ The system of monitoring the implementation of obligations includes specific provisions protecting the rights of each Member State. The enforcement branch makes its decisions by a double majority voting system. ${ }^{61}$ After the executive branch determines that

55 Xueman Wang, Glenn Wiser, "The Implementation and Compliance Regimes under the Climate Change Convention and its Kyoto Protocol", Review of European, Comparative \& International Environmental Law, CBlackwell Publishers Ltd, 11, 2/2002, 182.

${ }^{56}$ Schematic representation of the compliance mechanism laid down in the Kyoto Protocol, available at: https://unfccc.int/files/kyoto_mechanisms/compliance/application/pdf/comp_schematic.pdf, 03/5/18

${ }^{57}$ X. Wang, G. Wiser, 186. The targets are the same as the overall reduction of about $5.2 \%$ below the level of emissions by these countries in 1990 .

${ }^{58}$ X. Wang, G. Wiser, 188.

${ }^{59}$ The Marrakesh Accords, https://unfccc.int/cop7/documents/accords_draft.pdf, 22. 5. 2018. See the website of Compliance Committee: https://unfccc.int/process/bodies/constituted-bodies/ compliance-committee-cc, 22/ 5/2018

${ }^{60}$ See Sebastian, Oberthür, René, Lefeber, "Holding Countries to Account: The Kyoto Protocol's Compliance System Revisited after Four Years of Experience", Climate Law, 1/2010, 133-158.

${ }^{61}$ X. Wang, G. Wiser, 190. In this way, the efforts were made to alleviate the concerns of some Parties of Annex I that the geographical representation of members of the executive branch 
a Party has exceeded its emission target, the Party has the right to appeal the decision of the highest body of the Kyoto Protocol - the Conference of the Parties of the Kyoto Protocol. The appeal will be accepted only if the Party has not been allowed a fair trial in the course of enforcement proceedings. Execution of decision of the executive branch of the Committee shall not be executed until the decision on the appeal is made, while contested decision may be revoked or modified only by a two thirds majority vote of the Conference of the Parties. ${ }^{62}$ Facilitative branch for implementation of the Kyoto Protocol provides advice, make recommendations and provides financial and technical assistance. The executive branch is authorised to apply the "consequences" if the Party of Annex I failed to: (1) comply with the requirements for monitoring and reporting, (2) pass the tests of eligibility for participation in flexible mechanisms, or (3) meet its emission target. ${ }^{63}$

Although the Committee for monitoring the implementation has extensive authority, particularly in its executive branch, it is unlikely that the small island country will file claims for damages due to climate change for two reasons: first, the largest emitters of greenhouse gases remain outside the Kyoto Protocol (USA), as well as countries with strong economic growth (China and India), which are not legally bound to reduce their emissions, and secondly, the Committee for monitoring the implementation only investigates whether the Parties to the Kyoto Protocol comply with their obligations, but it has no authority to examine claims for damages caused by climate change. ${ }^{64}$ Therefore, it is concluded that the climate regime basically does not offer any possibilities for small island states to take legal action against the biggest emitters of greenhouse gases. ${ }^{65}$

Although the Kyoto Protocol provides for specific sanctions within the climate change regime for non-compliance with the obligations related to certain

could lead to unfair and politically motivated decision-making of the branch. Double majority voting means that a decision can be adopted only if approved by a majority of members of both blocks of the branch - countries of Annex I and those countries that are not included in Annex I.

${ }^{62} \mathrm{Ibid}$.

${ }^{63}$ Ibid.

64 T. Koivurova, 277. See more: https://unfccc.int/process/kyoto-protocol/compliance-under-kyoto-protocol/introduction, 17/ 5/ 2018

${ }^{65}$ T. Koivurova 277 op. cit. Rebecca Elizabeth Jacobs, Comment, "Treading Deep Waters: Substantive Law Issues in Tuvalu's Threat to Sue the United States in the International Court of Justice", Pacific Rim Law and Policy Journal 103/2005, 115. Tuvalu (later joined by Kiribati and the Maldives) in 2002 announced that it would initiate proceedings against Australia at the International Court of Justice. At the same time, Tuvalu stated that they were seeking refuge for its people as environmental refugees in Australia and New Zealand. See more: C. Voigt, 5. - A country has breached the international obligation only if the agreement that contains this obligation is in force in the country at the time of breaching the obligation. Therefore, large emitters of greenhouse gases that have not ratified the Kyoto Protocol, such as the USA, have no obligation of reduction, and cannot be held responsible for non-compliance with the objectives established by the Kyoto Protocol. 
reduction of greenhouse gas emissions, this system does not deal with the legal consequences of the damage caused by climate change. Therefore, provisions of general international law are applicable, but under certain circumstances they can have a "secondary role". In these cases, the Parties to the Kyoto Protocol must first use up the mechanisms prescribed by the protocol, but only when they prove ineffective, then they can turn to general international law. ${ }^{66}$ The Kyoto Protocol stipulates legally enforceable targets that countries have to achieve within certain deadlines regarding the reduction of greenhouse gas emissions, so that a state that does not meet its reduction target by the end of the deadline is considered to be in breach of its obligation under international law, and will in the coming binding period have to reduce emissions by 1.3 times ${ }^{67}$ However, in this agreement, there are no provisions dealing with compensation for the harmful consequences of climate change, although formally, the possibility of seeking compensation for damages due to breach of the obligations stipulated by the agreement has not been ruled out. There is no need to prove the negligent conduct of certain States, according to Tol and Verheyen, since the breach of the prescribed obligations constitutes the existence of wrongful acts as a necessary condition for initiating legal proceedings concerning compensation for the damage, which is to be attributed to the State which has exceeded the target prescribed by the Kyoto Protocol. However, such a request could only cover emissions above the target agreed with the respective State. ${ }^{68}$

\section{CHRONOLOGICAL OVERVIEW OF THE DEVELOPMENT OF CLIMATE DAMAGE CONCEPT IN NEGOTIATINS ON CLIMATE CHANGE AFTER KYOTO PROTOCOL}

Despite opposition from developed countries to any discussions about the moral and legal aspects of climate change, representatives of small island states have repeatedly emphasised the arguments regarding responsibility for climate changes. Alliance of small island states ${ }^{69}$ in 1991 proposed that the Intergovernmental Panel on Climate Change should establish an international security mechanism whose income would come from "necessary resources" of developed countries and which would be used to compensate for the damage to the most vulnerable small island states and developing coastal lowland areas. ${ }^{70}$ The concept

${ }^{66}$ C. Voigt, 5, according to Martti Koskenniemi, "Breach of Treaty or Non-Compliance?", Yearbook of International Environmental Law, 3/1992, 123.

${ }^{67}$ Articles 3 and 4 of the Kyoto Protocol.

${ }^{68} \mathrm{R}$. Tol and R. Verheyen, 1115 и 1116.

${ }^{69}$ Alliance of Small Island States - AOSIS

${ }^{70}$ Benoit Mayer, "Climate Change Reparations and Law and Practice of State Responsibility“, Asian Journal of International Law, 7/2017, 192. At that time, this proposal was given little 
of climate damages ("loss and damage") 71 is becoming increasingly present after a decade and a half, so the Bali Action Plan dating from 2007 calls for consideration of ways and means to address the damage associated with climate change in developing countries, which are particularly vulnerable to the adverse effects of these changes. ${ }^{72}$ Soon, however, this concept was put aside in tough negotiations mainly focused on climate change mitigation, so the developed countries, unlike developing countries which have asked to discuss liability and compensation, proposed an alternative focus on risk management through the mechanism of sharing risks and strategies for the reduction of disaster risk. ${ }^{73}$ In 2010 Cancun Agreement established a work programme assigned to the Subsidiary body for implementation, so as to consider appropriate approaches for addressing damage associated with climate change in developing countries that are particularly vulnerable through workshops and expert meetings. ${ }^{74}$ The Durban Conference in 2011 defined three thematic fields of this work programme in order to identify measures that can be taken in accordance with the Convention. ${ }^{75}$ Despite persistent opposition from developed countries to provide compensation for damages incurred as a result of climate change, they have gradually recognised that compensating for the climate damage requires taking certain financial measures.

Thus, at the 18th Conference of the Parties held in 2012 in Doha the Parties came to a compromise that the negotiations on the climate damage, among other things, should also deal with strengthening support to developing countries, including financial support through the establishment of an international mechanism. ${ }^{76}$

attention, as Bodansky said "The most vulnerable countries did not have much to offer to developed countries in exchange for financial transfers", D. Bodansky (1993), 501. See more: Lisa Vanhala, Cecilie Hestbaek, "Framing Climate Change Loss and Damage in UNFCCC Negotiations", Global Environmental Politics, 16, 4/2016, 115.

${ }^{71}$ Phrase "loss and damage", which has to be translated into Serbian as ,"šteta i šteta" (damage and damage) is specific in a way that it is particularly used for the damage incurred as a result of climate change, such as material and non-material damage, but actually it is used for the broadest context of damage to people, environment and whole community regardless of classical concept of casual link. Therefore, the most relevant translation of this term would be "climate damage".

72 Bali Action Plan (2007) - Decision I/CP.13 of the Conference of Parties (COP) to the UNFCCC. In the beginning the discussion was held within Ad Hoc Working Group on Long-term Cooperative Action under Convention - AHWGL.

${ }^{73}$ B. Mayer,193. See L. Vanhala and C. Hestbaek, 116-119

${ }^{74}$ B. Mayer, 193. Cancun Agreement comprised programmes covering adverse consequences in terms of extreme weather conditions and slow onset disasters, such as rising sea levels, increasing temperatures, ocean acidification, melting and retreat of the glaciers, salinization, land degradation and deforestation, loss of biodiversity and desertification.

75 The thematic areas are: (1) estimating climate damage risk, (2) developing various approaches to handling climate damages and (3) defining the role of the Convention.

${ }^{76}$ In the course of these negotiations, developed countries have expressed their opposition, especially the United States, to including any measures that could suggest the legal responsibility for the consequences of climate change in the text. See Vanhala L. and C. Hestbaek, 118. 
In 2013 in Warsaw, the Conference of the Parties established a Warsaw international mechanism for climate damage according to the Agreement on Adaptation of Cancun, ${ }^{77}$ which provides three types of functions: improving the understanding of a comprehensive approach to manage risks; strengthening the dialogue, coordinating, coherence and synergy among relevant interested parties; improving actions and support to enable developing countries to take action in addressing climate damage. ${ }^{78}$ In Lima in 2014, the Conference of the Parties was held when a two-year work plan of the Warsaw international mechanism on funding, that is meant to be revised at the Conference of the Parties in Paris, was approved. However, although Article 8 of the Paris Agreement stresses the importance of elimination, reduction or handling the compensation for damages incurred as a result of climate change, including extreme weather events and slow onset disasters, the accompanying provisions adopted at the 21st Conference of the Parties in Paris confirmed that it does not include or provide the basis for any responsibility or compensation..$^{79}$ Developed countries are obliged to provide funds to help developing countries in terms of mitigation and adaptation as a continuation of existing obligations under the Convention, so that funds come from different sources and channels, with a significant role of public funds in the context of a series of activities, including support to national strategies, taking into account the needs and priorities of the Parties in developing countries. ${ }^{80}$

From the above analysis it appears that many issues in International Law on Climate Change, and in General International Law, including the question of responsibility of States for non-compliance with obligations, are addressed through negotiation, development and elaboration of multilateral agreements, rather than through court proceedings. The negotiations allow the Parties to participate in controlling the outcome of the undertaken measures.

International climate change regime protects the autonomy of the Parties in decision-making in many ways, as Bodansky says, after "flirting" in the internati-

77 Warsaw international mechanism for loss and damage associated with climate change impacts, FCCC/CP/2013/L.15.

${ }^{78}$ Despite the efforts of G77, China, the Alliance of small island countries and representatives of the Philippines to consider climate changes outside the scope of adaptation, prevailed the efforts of developed countries, especially of the US and Australia, to discuss the issue of climate damages within the adaptation, with a compromise by recognising in the preamble to the decision establishing the Warsaw international mechanism, the fact that climate damages in some cases affect more than it is possible to reduce by the adaptation. See Vanhala L. and C. Hestbaek, 119 and 126.

${ }^{79}$ UNFCCC, Decision 1/CP.21, "Adoption of the Paris Agreement", paragraph 51, https:// unfccc.int/resource/docs/2015/cop21/eng/10a01.pdf, 14. 3. 2018. See L. Vanhala and C. Hestbaek, 120.

${ }^{80}$ Article 9 of the Paris Agreement. Paragraph 4 of the Article emphasises that the aim is to provide more funds for achieving a balance between adaptation and mitigation, with special attention given to developing countries and those most vulnerable to the negative impacts of climate change whose capacities are significantly limited, such as the least developed countries and small island developing states, taking into account the need to provide public and nonrefundable funds for adjustment. 
onal definition of the emission targets by the Kyoto Protocol, in the Paris agreement this regime is formed by using the bottom-up approach, allowing States to define their policy of emission reduction unilaterally by the nationally determined contributions $^{81}$, whereby the emphasis is put on different possibilities of adaptation and mitigation of certain States with respect to particular national circumstances. ${ }^{82}$

However, issues of sanctioning those who do not comply with the obligations and the possibility of injured parties to obtain compensation for damage caused by climate change, remain without a concrete and clear answer. Thereby, complying with the obligations prescribed by the Paris Agreement, that is internationally recognised, is not protected by the sanctions and the Parties themselves decide on mitigation and adaptation, but there is still no regulatory framework for the control of implementation of obligations. ${ }^{83}$ Vanhala and Hestbaek, in the analysis of defining the framework of climate damage through the UNFCCC negotiations, indicate that some countries, like the United States, address the issue of climate damage by adopting risk-reduction strategies and establishing mechanisms for the transfer or sharing of risk, while other countries, such as the Alliance of small island states, point out that apart from taking the risks into account, the question of responsibility, which includes the issue of compensation, should be posed.$^{84}$

\section{INTERNATIONAL CUSTOMARY LAW AS A SOURCE OF RULES ON STATES' RESPONSIBILITY FOR CLIMATE CHANGE}

Customary international law has developed from state practice and opinio juris, i.e. from the perception of the State that certain conduct actually reflects the

${ }^{81}$ Nationally Determined Contributions (NDCs)

${ }^{82}$ See D. Bodansky (2017), 691 и 695. See articles 3 and 4, paragraphs 2 and 3 of the Paris Agreement. See R. Verheyen, P. Roderick, 28.

83 "It won't work without tangible sanctions", an Interview with Anke Gerber, Universität Hamburg, by Giselind Werner (Вернер), 2017, https://www.uni-hamburg.de/en/newsroom/im-fokus/2017-11-07-klimakonferenz-gerber.html, 04/ 5/2018. Professor Gerber believes that, above all, it is necessary to constitute an independent institution that would be equipped with effective strategies of sanctions. It proposes a procedure in which the States would pay certain deposit insurance to an independent institution (e.g. The World Bank) after deciding on their policies. If the State meets its obligations, the deposit is returned to it, otherwise it loses the right to the return of a deposit. Deposit amount should be fixed at a sufficiently high rate so as to make particular countries feel compelled to meet their targets for purely economic reasons, rather than lose their deposit. See more: Anke Gerber, Philipp, Wichardt, "Providing Public Goods in the Absence of Strong Institutions", Journal of Public Economics, vol. 93, 3-4 /, 2009.

${ }^{84}$ L. Vanhala, C. Hestbaek, $121-124$. Supporters of the second opinion believe that the reduction in risk and insurance is suitable for some types of climate damage, such as those that occur due to extreme weather events, but they are not suitable when it comes to climate damages arising as a result of slow onset disasters (e.g., sea level rise), non-economic damages and lost development opportunities. 
rule of International Law. ${ }^{85}$ As we have already mentioned above, the principle of no-harm rule belongs to this legal category. Customary international law contains the basic rules whose violation leads to States' responsibility. In the field of law on environmental protection, this obligation becomes the obligation of committing no harm to the environment in other countries and areas within no one's jurisdiction (goods of general benefit to all mankind, such as space, atmosphere, etc.). ${ }^{86}$ Given that international law is, in essence, "the promise of justice", according to Mayer, moral dimensions of climate change must not be ignored, especially regarding the fact that nations and individuals who least benefit from the industrialisation and development, are often most affected by the adverse impacts of climate change. ${ }^{87}$ Therefore, the highlighted argument says that according to international law the developed countries are responsible for non-compliance with the obligations of reduction of greenhouse gas emissions within their jurisdiction. This argument is based on the violation of the no-harm rule, from which arises the obligation of the State to prevent activities within their jurisdiction that cause transboundary environmental harm. ${ }^{88}$ Mayer claims that compensation for damages from climate change should be designed with a special sensitivity to the unique and unprecedented nature of climate change, taking into consideration the relevant cases of the States' practice in the respective areas, which is in contrary to the strict application of certain rules on responsibility of the States codified by the International Law Commission. ${ }^{89}$

${ }^{85}$ R. Tol and R. Verheyen, 1114. See R. Etinski and S. Đajić, 27-34. See Vitomir Popović, Filip Turčinović, Public International Law, Faculty of Law, University of Banja Luka, 2009, 35-36.

${ }^{86} \mathrm{C}$. Voigt, $7-8-$ Although the customary law as a primary obligation whose disadvantage is manifested in certain ambiguity makes it difficult to clearly establish its content, an arbitration decision in the Trail Smelter case has had a strong influence on the formulation and content of this rule. This principle is also incorporated in principle 21 of the Stockholm Declaration and Principle 2 of the Rio Declaration. International Court of Justice in the Nuclear Weapons and the Gabcikovo-Nagymaros case confirmed that a general obligation of States to ensure that activities within their jurisdiction and control respect the environment of other States or areas beyond national control is part of the corpus of international law to protect the environment. Nuclear Weapons ICJ Report 241, 1996, 29; Gabcikovo-Nagymaros Project ICJ Report 7, 1997, 41.

87 B. Mayer, 185-216. Discussion on possible means to handle the compensation of damage caused by climate change in developing countries was initiated by the Bali Action Plan in 2007 and the Warsaw international mechanism for climate damage established in 2014.

${ }^{88}$ Ibid., 187. Mayer refers to the Trail Smelter Case (USA v. Canada), where it was determined that Canada is responsible for the damages and injuries caused by winds from the private lead smelter in Canada which is requested to prevent such damage in the future. The Court pointed out that it does not matter whether it will be decided based on the law of the United States or under general international law as long as the law of the United States is in line with the general rules of international law. See Principle 21 of the Declaration of the UN Conference on the Human Environment in Stockholm (1972), Principle 2 of the Rio Declaration of 1992. See Pulp Mills on the River Uruguay (Argentina v. Uruguay), Judgment, ICJ Reports, 2010, 14.

${ }^{89}$ While Article 31 paragraph 1 of the Draft stipulates that the responsible State is under obligation to make full reparation for the damage caused by the wrongful act, Mayer believes that the reparation should not or can be full. However, climate change is not the only situation where 
To establish the States' responsibility for damages due to climate change, it is necessary to identify legally relevant conduct of a State, or to attribute the activities of private individuals to the State. Emissions of carbon dioxide and other greenhouse gases are mostly a result of the activities of individuals and private industrial enterprises, coming from a variety of sources such as industrial plants, transportation, households, agricultural and livestock farms, forestry, etc., and these activities cannot be, ipso facto, attributed to the State. But even when the private sector manages activities that are causing harm to the environment, there is a duty of the State to exercise control over them, which is a concept of due diligence. ${ }^{90}$ Since the court cases, the States' practice, the contracts or scientific literature do not provide an appropriate response to the question of defining the concept of due diligence, each specific case should be considered separately and decision made on a case-by-case basis, it being understood that the management and conduct are of such kind that one can expect from a good government, but that the concept of due diligence is determined depending on the resources and opportunities in each country. ${ }^{91}$ Voigt names three components that need to be considered when defining the concept of due diligence: the ability to act or prevent the damage predictability and proportionality of selection of measures for preventing damage or reducing the risk of damage. The conduct of the State in accordance with the concept of due diligence requires that the State takes all necessary measures at its disposal to prevent the occurrence of significant damage, including taking appropriate preventive measures even when there is no full scientific certainty in this regard, which is in accordance with the precautionary principle. This means that the conduct of the State in accordance with the concept of due diligence is not static standard, but on the contrary, it can vary, for example by scientists who can assess that the risk and the resulting adverse effects are significantly higher than previously thought. Therefore, States are required to keep up with scientific developments and technological changes, and that mitigation measures required to reduce greenhouse gas emissions are based on the best available technologies. ${ }^{92}$

full reparation does not constitute a suitable solution for liability claims, there are also: wars and other mass atrocities, measures in trade, expropriation and dangerous activities. B. Mayer, 198.

${ }^{90}$ This principle has been applied in the case of Nauru. Namely, Australia, New Zealand and the United Kingdom have signed an agreement that resulted in the destruction of land of Nauru due to the extraction of phosphate. The agreement explicitly stated that the extraction of phosphate is to be governed by private employers without government intervention, which the Court found to be the failure of ability and power of the State to regulate and control these activities in order to prevent the destruction of the environment, which is why responsibility was attributed to Australia. Certain Phosphate Lands in Nauru (Nauru v. Australia), ICJ Reports 1992, 240. See https://www.icj-cij.org/en/case/80, 04. 6. 2018, respectively.

${ }^{91}$ C. Voigt, 10. Op .cit. R. Verheyen (2005), 174.

${ }_{92}$ Article 10, paragraph 1 (C) and (d) of the Kyoto Protocol; Article 10, paragraph 4 of the Paris Agreement states that what is being established is technological framework for the provision 
In the context of the damage due to climate change, almost every country has the ability to take preventive measures or to reduce the risk of such damages. However, due to the cumulative effect of greenhouse gas emissions it is difficult to prove that one or more countries could prevent the occurrence of the violation. ${ }^{93}$ In order to determine the existence of States' responsibility in these situations, the key criterion is whether the countries have taken (if they are able to take) appropriate action to reduce greenhouse gas emissions, which would lead to a substantial reduction in the contribution of these States to future damages due to climate change. Otherwise, by definition on responsibility, there would be no basis for the States' responsibility when there are more pollutants that commit the breach. This approach, according to Tol and Verheyen, has been adopted in national legislation, and could be a general principle applicable in international law. ${ }^{94}$ Due diligence is an obligation to take every effort, which is particularly important with regard to the cumulative emissions of greenhouse gases. ${ }^{95}$ As regards the requirement of foreseeability of damage, the corresponding relationship between the omission (for example, regulating the reduction of greenhouse gas emissions) and harmful consequences of this failure could be established when the State knows or foresees, or is supposed to know or predict, that its conduct is or will be part of a complex of causes that lead to the occurrence of damage. ${ }^{96}$ It is considered sufficient that the State is able to predict the general consequences of its action or omission. When it comes to anthropogenic climate change, it is known that increasing concentration of greenhouse gases leads to a rise in average temperatures, resulting in a number of damages, and there is little room for the state to claim that it did not know the facts about the anthropogenic causes of climate change on which there is almost universal scientific consensus. All countries that are Parties to the UNFCCC are familiar with the fact that climate change is a real

of comprehensive guidelines for the operation of the Technology Mechanism defined by the Convention on the promotion and facilitation of measures for the development and transfer of technologies in order to support the implementation of the Paris Agreement with the aim of increasing resilience to climate change and reducing greenhouse gas emissions - Best Available Technologies.

${ }^{93}$ See R. Etinski, S. Đajić, 591 - Global pollution is the one that causes adverse international repercussions, but the process of pollution is formed in a way that a causal link between the source of pollution on the territory of the one State and the harmful effects on the territory of the other State cannot be established, as is the case with the cross-border pollution. Differentiation of global and cross-border pollution is internationally relevant because of the different possibilities of international treatment of the two international processes.

${ }^{94} \mathrm{R}$. Tol, R. Verheyen, 1117 and 1118

${ }^{95}$ R. Verheyen, P. Roderick, 18, op.cit. Riccardo Pisillo-Mazzeschi, "Due Dilligence Rule and the Nature of the International Responsibility of States", German Yearbook of International Law 35, 9/1992, 48.

${ }^{96}$ R. Tol, R. Verheyen, 1117 and 1118, op. cit. the Report of the Commission for International Law from 64th Conference (1990). 
threat and "common concern of mankind". ${ }^{97}$ As discussed above, the determination of proportionality depends on specific facts and circumstances of the case. Harmful effects due to climate change are most often reflected in the loss of land, a lot of harm to human health and their property and potential victims. Some States, including small island states and coastal lowland zones, are affected a lot by a significant loss of territory, and only significant reduction of greenhouse gas emissions could be considered proportionate measure of the emitter state in relation to the damage. ${ }^{98}$ However, not all States have equal opportunities or capacity to reduce their emissions, and the principle of justice can be applied, which means that the requirements for the reduction of greenhouse gases comply with current capacity of the state to prevent the damage, which is in accordance with the principle of common and differentiated responsibilities and respective competencies of Article 3.1 of the UNFCCC. This principle is a formal exception from the strict and equal treatment of States under international law and could have an impact on the constitution of proportionate measures in each case. In this context, it is very important that the States comply with the obligation to cooperate and to consult on preventive measures, to exchange information in order to carry out assessments of environmental impacts in all cases in which damage is likely to occur. This practice is successfully established in most national legislations and can be considered a general principle, or even international customary rule, achieved by Consensus reflected in principle 17 of the Rio Declaration on environment and development in 1992, and in Article 7 of the Commission draft rules of international law on the prevention of transboundary harm from hazardous activities, requiring the implementation of a risk assessment, especially for projects or industrial activities due to which, although not expected, it is possible that the damage occurs. ${ }^{99}$

Regarding the concept of due diligence, some harmful activities that are still not prohibited as such, or are important for the economic development of certain States, should at least be notified and consulted with potentially affected States, and appropriate measures should be taken in order to protect the States' territory and the environment. These obligations require that major emitters of greenhouse gases hold consultations with the States that are most likely to be affected by the

${ }^{97}$ C. Voigt, 12. Each State has discretion in choosing ways and means to reduce greenhouse gas emissions

${ }^{98} \mathrm{Ibid}, 13$. This is in accordance with the performed economic analysis of costs due to climate change in relation to the benefits from a strong and early action to mitigate climate change, as it was concluded in the Stern Review: The Economics of Climate Change (2006) that the benefits of mitigation actions significantly outweigh the costs, which means that if the action is taken earlier, the costs are lower. See more R. Verheyen, P. Roderick, 20

99 C. Voigt, 14. See Draft articles on Prevention of Transboundary Harm from Hazardous Activities, with commentaries (2001), http://legal.un.org/ilc/texts/instruments/english/commentaries/9_7_2001.pdf, 19/4/2018 
impacts of climate change. In this context, there is the customary legal obligation to achieve an equitable solution. This principle may be applied by analogy to the use of atmosphere as a common good of mankind, as indicated in the preamble to the Convention, which implies that States have an equal right to use the atmosphere as much as they have the right not to be endangered by dangerous anthropogenic interference with the climate system. Therefore, the obligation to consult and reach a fair solution could, in principle, be applied to issues of climate change. For this purpose, it can be argued that states have an obligation not only to reduce their emissions, but also to effectively prevent any damage as a result of climate change.

\section{CONCLUSION}

It is necessary to provide adequate legal protection of the atmosphere as a common good of the mankind not only at the declarative level. It is also important to consistently apply the appropriate legal rules in reality and seek mechanisms to control the implementation of these rules and appropriate sanctions for those who violate them. However, in the international law of climate change, difficulties in establishing the elements of responsibility for damages incurred as a result of climate change are evident since there is a very complex interaction relationship between the climate system and a man, with non-linear and complex causes of climate change, and it is almost impossible to establish a causal link between the conduct of a particular State (or States) and a specific and concrete damage caused by climate change. Therefore, the issue of States' responsibility for non-compliance with obligations under the Law on climate change is approached through negotiation and development of multilateral agreements, and there is no litigation before the International Court of Justice or before International Arbitration Tribunals for the time being. International climate change regime protects the autonomy of the Parties in making decisions on measures to combat climate change. Consequently, the UN Framework Convention on Climate Change does not stipulate clear and specific obligations of the Parties in terms of setting limit values for emissions of greenhouse gases, which is done only by the Kyoto Protocol. However, neither the Kyoto protocol, which in the sphere of control over meeting obligations has certain possibilities regulated by mechanism for monitoring their implementation, provides for the possibility of determining the damage caused by climate change, nor does it stipulate decisions on the eventual requirements of the State for compensation for the damage. Paris Agreement has allowed the Parties to define their policies to reduce greenhouse gas emissions through nationally defined contributions, with emphasis on the different possibilities of adaptation and mitigation of some countries with regard to specific national circumstances. 
Although Article 8 of the Paris Agreement emphasises the importance of eliminating, reducing or handling compensation for damage due to adverse consequences of climate change, including extreme weather events and slow onset disasters, accompanying provisions adopted at the 21st Conference of the Parties in Paris confirmed that it does not include or provide the basis for liability or compensation. When the basis of international responsibility is customary law on concept of due diligence and the States' obligation to act with due diligence, i.e. to take all necessary measures to prevent damage due to climate change, there is also certain flexibility, which means respecting the capacity and ability of the state to reduce its greenhouse gas emissions regarding their particular circumstances and possibilities.

Therefore, we can conclude that the responsibility of the States for climate change is still quite controversial area of international law. Namely, the applicable international regulations provide a mechanism for implementation of international rules in the legal systems of the States, the mechanism of complying with the obligations and respect for different possibilities of adaptation and mitigation of some countries with regard to specific national circumstances. However, the current international regulations on climate change in their provisions do not explicitly specify that non-compliance with obligations is the basis of the international responsibility of States, nor they determine the sanctions to those that do not comply with obligations, which implies that multilateral international treaties in this field of law, as such, are insufficient guarantee that the Parties will duly fulfill their contractual obligations. Considering numerous specificities of climate change law, adversarial nature of traditional practices and the international responsibility of States do not correspond precisely to the nature of climate change and the lack of a clear causal link. In doing so, it is necessary to find a more efficient solution in the form of an appropriate mechanism or mechanisms (material and processed) to ensure consistent compliance with contractual obligations of all Parties, and thus achieve a necessary objective, which is to reduce greenhouse gas emissions and stabilise the temperature to a certain level, with the ultimate goal of preserving the environment on Earth. These mechanisms should cover both the risk reduction strategies and establishing mechanisms for transferring or sharing the risk and sanctioning of the Parties that do not comply with the obligations, as well as the possibility of compensation for the Parties that have suffered damage due to climate change. 


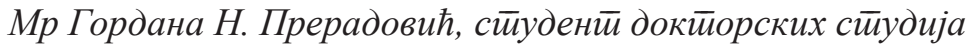
Универзитетеи у Бањој Луци

Правни Факулиеети у Бањој Луции

preradovic.goga@gmail.com

\section{Међународноправна одговорност држава за климатске промјене}

Сажейак: Климайске иромјене имају далекосежне шииейне иосљедиие йо еколошке систиеме, људске живоие и здравље и економски найредак,

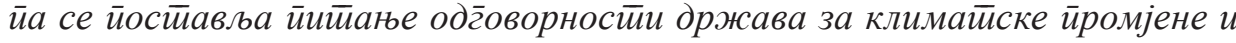

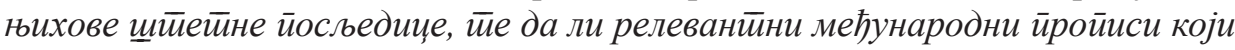
се баве климайским иромјенама (Оквирна конвениија Уједињених наиија о иромјени климе, Кјойо иротиокол и Парищки сиоразум) иройисују и дефинищу

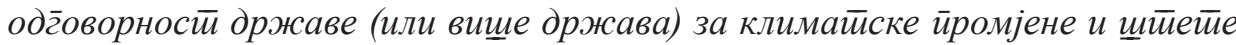

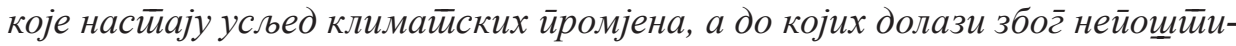
вања ирреузетиих обавеза из наведених међународних докуменайа. У кониеккстичу климайских ирромјена иримарна обавеза држава је да редукују своје

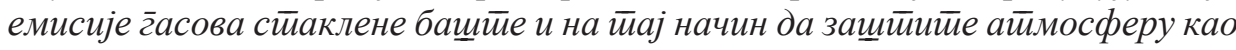
ойшиме добро иијелог̄ човјечанстива. У новије вријеме се све већа йажњ а йосвећује иррилаг̄ођаваюу на шитеитне ефектете иромјене климе, као и обавезама развијених држава да йомог̆ну неразвијеним државама и државама у развоју, које су уједно и најосјейљивије на шиметине иосљедице климайских ирромјена, у финансирању и сирровођену мјера ирилагоођавања. У раду анали-

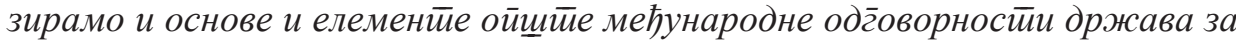

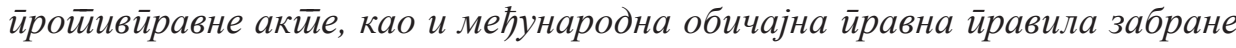

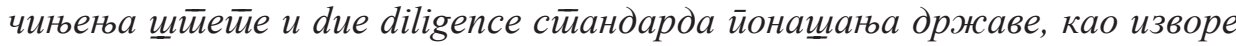
међународне одг̄оворности држава које крще наведена обичајна ирравна иравила.

Кључне речи: климайске йромјене, међународна одг̄оворности држава, механизам йосииуйања йо ирреузетиим обавезама.

Датум пријема рада: 11.06.2018. 